\title{
High Throughput Optical Biosensor for Monitoring Pb (II) Ions in Milk through Fluorescence based Microarray Approach
}

Hardeep $\mathbf{K}^{1,2 *}$ and Verma $\mathbf{N}^{1}$

${ }^{1}$ Biosensor Technology Laboratory, Department of Biotechnology, Punjabi University, Patiala, Punjab, India

${ }^{2}$ Department of Biotechnology, Baba Farid College, Bathinda, Punjab, India

\begin{abstract}
Milk is a bulk consumer product therefore it serves a versatile source of public exposure to contaminants. Among the various heavy metals, lead has been recognized as the leading environmental health threat and milk has been found mostly contaminated with high levels of $\mathrm{Pb}$ (II) ions. In present study an optical biosensor is developed employing Bacillus sphaericus (MTCC 5100) as biorecognition unit and the analysis is based on urease inhibition resulting in fluorescence change. Investigation was carried out by means of fluorescence dye (Rhodamine 6G) in hydrophobic environment with the heavy metal. The novelty of the method lies in the formula that is devised to detect equivalent $\mathrm{Pb}$ (II) ions in milk in the presence of $\mathrm{Cd}$ (II). Lowest detection limit achieved is $0.48 \mathrm{nM} \mathrm{Pb}$ (II) equivalents in spiked milk samples (permissible limit $96.6 \mathrm{nM}$ ). This is the first report on low level $\mathrm{Pb}$ (II) monitoring in milk through high throughput microarray biosensing.
\end{abstract}

Keywords: Urease; Hydrosol-gel immobilization; Fluorescence; Microarray; Lead; Milk biosensor

\section{Introduction}

Lead $(\mathrm{Pb}$ II) has gained the attention of all the health authorities and concerned departments due to its increasing contamination level and worldwide occurrence [1-3]. The permissible limit of lead has been reduced to $10 \mu \mathrm{gl}^{-1}$ in drinking water and $20{\mu \mathrm{gl}^{-1}}^{-1}$ in milk [4]. Recent reports have shown an overall increase of lead levels in milk, as a consequence, monitoring of lead becomes essential. Swarup [5] revealed that the lactating cows with a blood lead level (BLL) above $200 \mathrm{\mu gl}^{-1}$ have significantly higher milk lead excretion than those below that level. So a simple and highly sensitive method is needed to check lead contamination in milk. As an analytical tool, biosensors hold the advantage of simplicity, portability, cost effectiveness and ability to analyze bio-available toxicity level of analyte over the conventional techniques.

Various approaches have been used by different researchers to develop biosensor for lead. Durrieu and Tran - Minh [6] reported inhibition of alkaline phosphatase in the presence of lead as a bioassay principle for the development of an optical algal biosensor. Kuswandi [7] employed fiber optic technology, to develop an optical $\mathrm{Pb}$ (II) biosensor. Urease activity based optical biosensor was developed by Tsai [8]. Later a multi analysis 50 spot array based optical biosensor was developed by Tsai and Doong [9], the sensor was based on basic principle of inhibition of urease and acetylcholinesterase by heavy metals. Both the enzymes were co - immobilized with FITC dextran in sol - gel matrix for multianalyte detection. The biosensor demonstrated detection range from $10 \mathrm{nM}$ to $100 \mathrm{nM}$ for Cd (II), $\mathrm{Hg}$ (II) and $\mathrm{Cu}$ (II), but no response was observed against $\mathrm{Pb}$ (II). Haron and Ray [10] developed a biosensor based on inhibition of urease and acetyl cholinesterase by $\mathrm{Pb}$ (II) and a detection limit of $4.83 \mathrm{nM}$ was achieved using cyclotetrachromotropylene (CTCT) as an indicator. Gani et al. [11] constructed an optical biosensor by immobilizing urease and a $\mathrm{pH}$ indicator chlorophenol red in a PVC-sol-gel matrix for monitoring heavy metals in water samples. A liquid crystal (LC) based optical biosensor has also been developed [12]. In this case urease was immobilized on a UV - tailored nematic LC called 4 - cyano - 4' pentyl biphenyl (5CB). In the presence of heavy metal ion, the optical characteristic of LC remained unchanged in urea solution. Above discussed studies firmly elucidate that biosensors are promising tool for accurate real time monitoring of heavy metals in environmental samples. The present work is also focused on the development of a simple biosensor for fast and economical monitoring of $\mathrm{Pb}$ (II) ions in water and milk samples.

Present work lead to two innovations, first is the use of a fluorescent dye Rhodamine $6 \mathrm{G}$ ( $\mathrm{Rh}-6 \mathrm{G}$ ) as the $\mathrm{pH}$ indicator for $\mathrm{Pb}$ (II) monitoring and secondly the immobilization of the same in a hydrophobic sol gel environment to achieve a portable biosensor assembly with multiple sampling capability. Tetra-ethylorthosilicate (TEOS) has been used as the precursor for sol-gel matrix, which gets hydrolyzed with addition of water, and after condensation reaction lead to the formation of semi -solid $\mathrm{Si}-\mathrm{O}-\mathrm{Si}$ linkages. Due to the organic composition, the dye is easily soluble in protonated form in this matrix and its fluorescence intensity remains unaffected. The hydrolysis of urea by urease produces ammonia which is captured in the cross linked sol-gel matrix along with Rhodamine 6G. This association of ammonia and Rhodamine 6G creates the perfect circumstances for deprotonation of the later and formation of ammonium ions with decrease in the fluorescence [13].

$$
\mathrm{Rh} 6 \mathrm{G}-\mathrm{H}^{+}+\mathrm{NH}_{3} \rightarrow \mathrm{Rh} 6 \mathrm{G}+\mathrm{NH}_{4}^{+}
$$

The bioassay characterization was based on the well known inhibition phenomenon of urease enzyme by the heavy metal. The ammonia produced from urea hydrolysis (catalyzed by urease) was subjected to the dye and the fluorescence was checked before and after the reaction. The inhibition of urease in the cell was detected by increase in fluorescence as compared to control, as in the presence of

*Corresponding author: Hardeep K, Biosensor Technology Laboratory, Department of Biotechnology, Punjabi University, Patiala, Punjab, Tel: 91-9646773958; E-mail: hardeep_kaur007@rediffmail.com

Received March 14, 2015; Accepted June 11, 2015; Published June 21, 2015

Citation: Hardeep K, Verma N (2015) High Throughput Optical Biosensor for Monitoring $\mathrm{Pb}$ (II) lons in Milk through Fluorescence based Microarray Approach. J Biosens Bioelectron 6: 166. doi:10.4172/2155-6210.1000166

Copyright: (c) 2015 Hardeep K, et al. This is an open-access article distributed under the terms of the Creative Commons Attribution License, which permits unrestricted use, distribution, and reproduction in any medium, provided the original author and source are credited. 
heavy metal less ammonia was produced which caused less amount of dye deprotonation.

\section{Materials and Methods}

Rhodamine 6G solutions was purchased from Sigma-Aldrich (ST. LOUIS, MO, USA). Reagents like ethanol, Tetra-ethylorthosilicate (TEOS), $\mathrm{NaOH}$ were purchased from Merk and HIMEDIA, Mumbai, India. Standard solutions of $\mathrm{Pb}$ (II) and $\mathrm{Cd}$ (II) were purchased from MERCK KGAA, Germany and stored in plastic bottles at $4^{\circ} \mathrm{C}$ after dilutions.

The optical biosensor for lead was constructed using urease producing B. sphaericus whole cells which were found to be sensitive against lead upto nanomolar levels [14]. Concentration of Rhodamine 6G was optimized to get the most favorable fluorescence for the analysis. Whole cells of $B$. sphaericus were immobilized with hydrosolgel method in the micro well plate [15]. A mixture of $530 \mu \mathrm{l}$ ethanol, $50 \mu \mathrm{l}$ TEOS, $10 \mu \mathrm{l} \mathrm{NaOH}(5 \mathrm{mM}), 80 \mu \mathrm{l}$ Rh-6G dye, $10 \mu \mathrm{l}$ B. sphaericus whole cells $(0.14 \mathrm{U})$ was prepared and incubated at $4^{\circ} \mathrm{C}$ for $1 \mathrm{hr} .20 \mu \mathrm{l}$ of the mixture was then poured in each well followed by $20 \mu \mathrm{l}$ of $\mathrm{Pb}$ (II) and 2M urea solution each for lead analysis. The fluorescence was read at the zero time after addition of all reagents and after $10 \mathrm{~min}$ incubation at $37^{\circ} \mathrm{C}$. The direct immobilization of B. sphaericus needed the selection of wells with same initial fluorescence. To overcome this problem a slight modification of the above method was made, in which the hydrosol gel mixture [530 $\mu$ l ethanol, $50 \mu \mathrm{l}$ TEOS, $10 \mu \mathrm{l} \mathrm{NaOH}(5$ $\mathrm{mM}), 152 \mu \mathrm{l} \mathrm{Rh}-6 \mathrm{G}(1.22 \mu \mathrm{M}), 10 \mu \mathrm{l}$ B. sphaericus whole cells $(0.14$ $\mathrm{U})$ ] was taken in a tube and kept at $4^{\circ} \mathrm{C}$ for $1 \mathrm{hr}$. The dye content was increased because the overall volume in this method was much more than the previous method. Then $1 \mathrm{ml}$ lead (1-10 $\left.\mathrm{ng} \mathrm{ml}^{-1}\right)$ and $1 \mathrm{ml}$ urea $(2 \mathrm{M})$ were added to the mixture and half of the reaction mixture was taken out to take zero time reading and the next half given $10 \mathrm{~min}$ incubation at $37^{\circ} \mathrm{C}$ after which its fluorescence was read. $20 \mu \mathrm{l}$ from each tube was taken in wells for fluorescence read and a number of samples were possible at the same time in a 48 well microwell plate. The optimized method was used to check lead contamination in water, spiked milk samples and unknown milk samples from rural, urban and industrial areas. All the experiments were conducted in triplicates and standard deviation was applied to all results to obtain error bars.

As lead and cadmium are the main contaminating metals found in milk $[1,3,16,17]$ lead analysis in the presence of cadmium was optimized in water system and then applied to spiked and unknown milk samples. For cadmium detection $B$. badius was used as the sensing element as it was found to be sensitive against cadmium up to $0.1 \mathrm{ng} \mathrm{ml}^{-1}[18]$ and is not sensitive to lead up to microgram levels. This fact helped to check the cadmium concentration in the sample without any interference by lead. The fluorescent dye Acridine orange (Ex at $502 \mathrm{~nm}$ and Em at 526 $\mathrm{nm})$ working on the same principle as Rhodamine- $6 \mathrm{G}\left(\mathrm{E}_{\mathrm{x}}=526 \mathrm{~nm}\right.$, $\mathrm{E}_{\mathrm{m}}=555 \mathrm{~nm}$ ) was used for the signal transduction. The Acridine orange and Rhodamine- $6 \mathrm{G}$ has been used as they have different emission wavelengths and hence can be used for simultaneous detection of lead and cadmium in the same well. For simultaneous detection of both the metals, composition of hydrosol- gel mixture was modified to $500 \mu \mathrm{l}$ ethanol, $50 \mu \mathrm{l}$ TEOS, $10 \mu \mathrm{l} \mathrm{NaOH}(5 \mathrm{mM}), 152 \mu \mathrm{l} \mathrm{Rh}-6 \mathrm{G}(1.22 \mu \mathrm{M}), 45$ $\mu \mathrm{l}$ Acridine orange, $10 \mu \mathrm{l}$ B. sphaericus whole cells $(0.14 \mathrm{U})$ and $10 \mu \mathrm{l}$ $B$. badius whole cells $(0.29 \mathrm{U})$. The system was first optimized for water samples and then applied to milk samples. The hydrosol- gel mixture was incubated at $4^{\circ} \mathrm{C}$ for $1 \mathrm{hr}$, then $0.5 \mathrm{ml}$ each of lead and cadmium (1$20 \mathrm{ng} \mathrm{ml}^{-1}$ ) was added along with $1 \mathrm{ml}$ urea (2M). Further analysis was made as in previously mentioned protocol and according to the lead and cadmium detection limits achieved in a single well, standards for both individual and simultaneous detection were prepared and applied to device a formula to unknown milk samples.

\section{Results}

The results obtained were statistically verified to achieve minimum error level and precise detection limit. All the results are presented with error bars that depict the standard deviation range. To develop an optical microarray based biosensor for multiple sample analysis, Rhodamine $-6 \mathrm{G}\left(\mathrm{E}_{\mathrm{x}}=526, \mathrm{E}_{\mathrm{m}}=555\right)$ was used as the indicator dye. The dye was optimized for linear concentration response in the microwell plate. A volume of $80 \mu \mathrm{l}$ of $1.22 \mu \mathrm{M}$ dye in a total of $680 \mu \mathrm{l}$ sol gel mixture was found most appropriate according to the linear curve (Figure 1) after which the intensity of fluorescence reached pseudozero order stage. $\mathrm{Pb}$ (II) was analyzed by setting the Rhodamine immobilized hydrosolgel directly into the microarray plate and then adding different lead concentrations in the wells with same initial fluorescence. Rhodamine was completely soluble in the sol-gel mixture. An initial drop in Rhodamine fluorescence in the control assay (not containing $\mathrm{Pb}$ II), followed by increase with consecutive addition of lead, as expected from the $\mathrm{Pb}$ (II) bioassay principle was observed. Whole cells of $B$. sphaericus were used as the sensing component with enzyme activity $14.97 \pm 2.01 \mathrm{IU}(250 \mathrm{ml}$ broth$)$. The lead inhibition effect was found to be logarithmic in this case and the linear range of detection was found to be $4.83 \mathrm{nM}-4.83 \mu \mathrm{M} \mathrm{Pb}$ (II) equivalents. The lower limit of detection in this method was $4.83 \mathrm{nM} \mathrm{Pb}$ (II) equivalents.

Although this method was sensitive, it had the disadvantage of selection of wells with same fluorescence intensity and many unutilised wells, hence wastage of biomass and reagents. To combat this problem, a modificaion in the protocol was made. This method provided repeatability of the results and linear range of lead detection achieved was $0.48-9.66 \mathrm{nM} \mathrm{Pb}$ (II) equivalents with lowest detection limit of 0.48 $\mathrm{nM} \mathrm{Pb}$ (II) equivalents (Figure 2, results are presented as logarithmic relationship of cadmium with enzyme activity, standard deviation was applied to triplicate experiments)).

Owing to the repeatibility and lower limit of detection of lead, this method was further applied for lead analysis on spiked milk samples. In case of spiked milk samples ( $1 \mathrm{ml}$ volume used) the linear range of

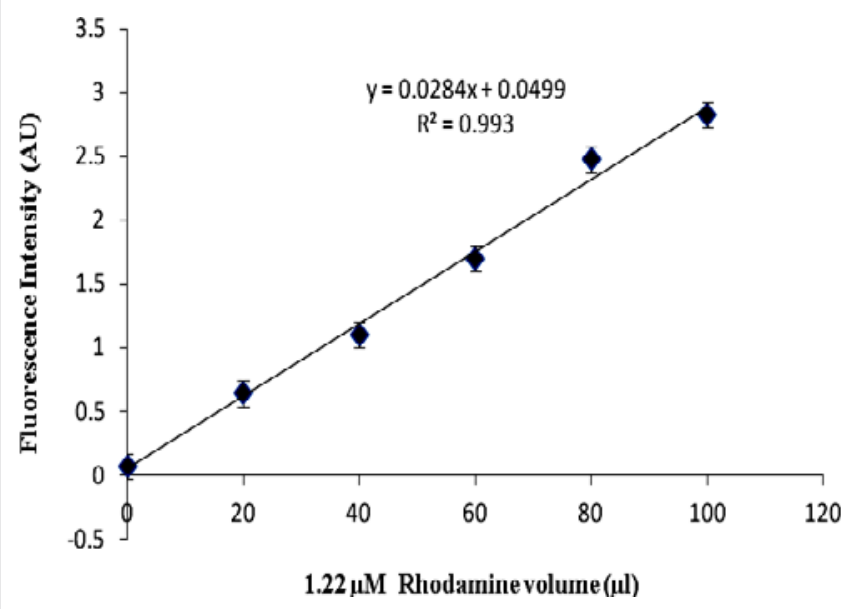

Figure 1: Fluorescence response of $1.22 \mu \mathrm{M}$ Rhodamine $6 \mathrm{G}$ dye at various volume levels in the detection vial containing $680 \mu \mathrm{l} \mathrm{sol}-$ gel mixture. 


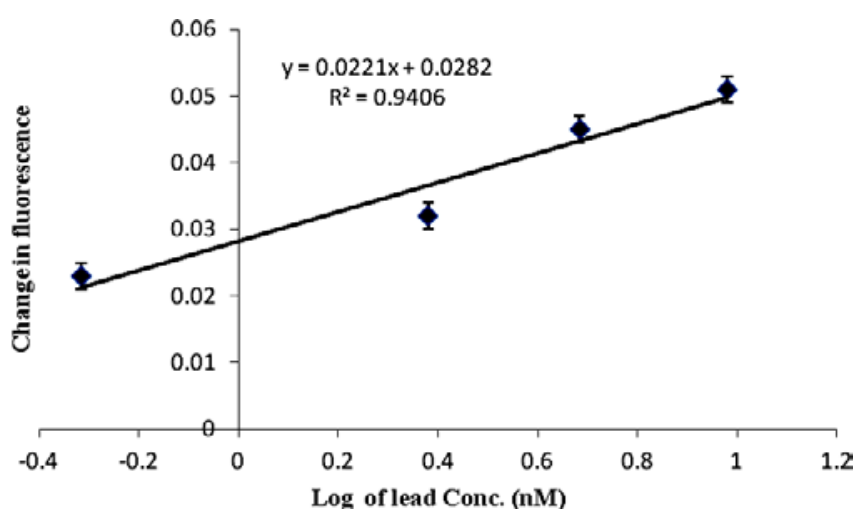

Figure 2: Logrithmic relationship of lead concentration with enzyme activity The Linear range of detection achieved was $0.48-9.66 \mathrm{nM} \mathrm{Pb}$ in modified microarray method (result obtained by applying standard deviation to triplicate experiments).

\begin{tabular}{|c|c|c|c|}
\hline $\begin{array}{c}\text { Lead Concentration } \\
\text { (nanomoles) }\end{array}$ & $\begin{array}{c}\text { Fluorescence in } \\
\text { water system }\end{array}$ & $\begin{array}{c}\text { Fluorescence in } \\
\text { spiked milk sample } \\
\mathbf{( 1 0} \boldsymbol{~ \mu l )}\end{array}$ & $\begin{array}{c}\text { Fluorescence } \\
\text { difference }\end{array}$ \\
\hline Control & 0.502 & 0.641 & 0.139 \\
\hline $4.8 \times 10^{-4}$ & 0.525 & 0.654 & 0.129 \\
\hline $2.4 \times 10^{-3}$ & 0.534 & 0.653 & 0.119 \\
\hline $4.8 \times 10^{-3}$ & 0.547 & 0.667 & 0.120 \\
\hline $9.7 \times 10^{-3}$ & 0.553 & 0.671 & 0.119 \\
\hline $2.4 \times 10^{-2}$ & 0.581 & 0.683 & 0.102 \\
\hline
\end{tabular}

Table 1: Comparison of fluorescence in water and spiked milk samples

detection was from $0.48-48.3 \mathrm{nM} \mathrm{Pb}$ (II) equivalents in a logarithmic pattern with lowest limit of detection $0.48 \mathrm{nM} \mathrm{Pb}$ (II) equivalents. To apply the developed method to unknown samples and showcase the fluorescence difference in water and milk matrix, fluorescence of different $\mathrm{Pb}$ (II) concentrations was compared in water and milk system as shown in Table 1.

The detection of lead and cadmium simultaneously was made possible by using two urease producing strains, B. sphaericus and $B$. sphaericus respectively. Two different fluorescent dyes Rhodamine 6G $\left(\mathrm{E}_{\mathrm{x}}=526 \mathrm{~nm}, \mathrm{E}_{\mathrm{m}}=555 \mathrm{~nm}\right)$ and Acridine orange $\left(\mathrm{E}_{\mathrm{x}}=493 \mathrm{~nm}, \mathrm{E}_{\mathrm{m}}=535\right.$ $\mathrm{nm}$ ) with different emission wavelengths (Figure 3) were selected for this purpose. Also there was an advantage that $B$. badius urease is insensitive to lead at nanomolar levels and demonstrate inhibition only at micromolar range [18], whereas B. sphaericus is sensitive to lead at nanomolar levels. So lead does not interfere in cadmium detection by $B$. badius and the fluorescence read against Acridine orange corresponds to cadmium effect only, but the fluorescence read using B. sphaericus is the cumulative effect of lead and cadmium. Regarding the cytotoxicity of heavy metal ions against Bacillus sp, it needs to be mentioned that it's been preinvestigated by authors that $\mathrm{Pb}$ (II) and $\mathrm{Cd}$ (II) ions demonstrate variable range of response against Bacillus sp [14,18]. The Bacillus sphaericus employed in the present study has also been reported to illustrate response against other heavy metals such as Nickel [19] and copper [20]. The effect of lead and cadmium on Bacillus species has been tested by other workers also. Bacillus sphaericus has been employed as bioaccumulator of lead ions in a study [21]. A Diaion SP-850 resin loaded with B. sphaericus was experimented to preconcentrate and separate the metal ions from liquid and solid samples in the detection range of $0.2020-0.75 \mu \mathrm{g} \mathrm{L}^{-1}$ and
2.5- $9.4 \mathrm{ng} \mathrm{g}^{-1}$ respectively. Owing to higher bioaccumulation capacity of Bacillus sp, an endophytic strain Bacillus sp. MN3-4, isolated from the roots of Alnus firma plant is reported [22]. Lead was accounted to be extracellularly sequestered by the microbe that confirmed a higher degree of toxicity tolerance of Bacillus sp. against lead ions. The linear range of detection of cadmium was obtained in the range of $0.5-24 \mathrm{nM}$ for water and spiked milk samples as depicted in Figure 4 (results are presented as logarithmic relationship of cadmium with enzyme activity; standard deviation was applied to triplicate experiments). The viability of both the Bacillus strains has been reported in author's previous research work $[14,18]$ that revealed a storage stability of approximately two months in sol- gel hydrophobic environment

The reliability of the developed method and the formulas was checked by carrying out lead and cadmium analysis in unknown samples and then again after spiking of the samples with known concentration of lead and cadmium. All the samples were analyzed in triplicates and the devised formula was applied to the fluorescence read to detect lead

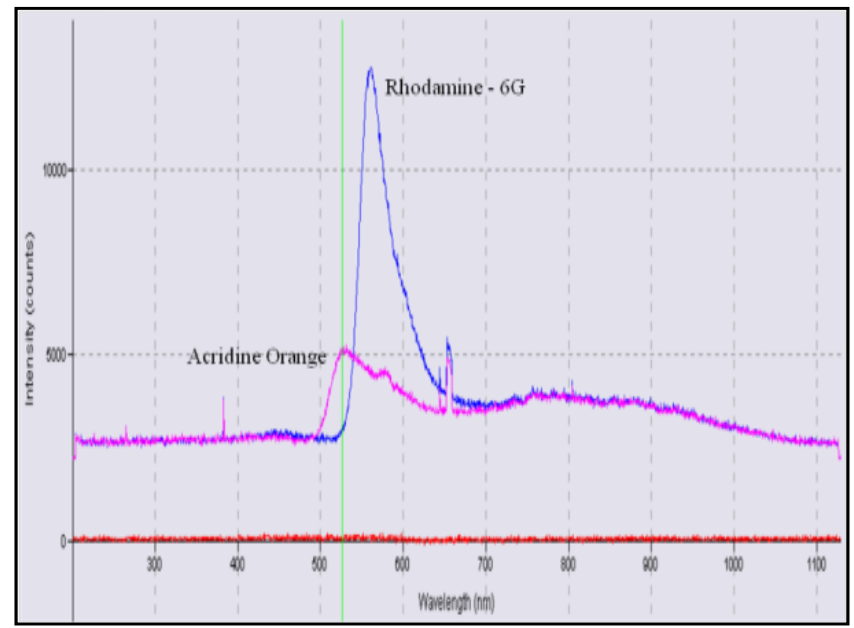

Figure 3: Emission Spectra od Rhodamine 6G at Emission wavelenth Ex 555 $\mathrm{nm}$ and Acridine Orange Ex $535 \mathrm{~nm}$, without any biological component in the assay.

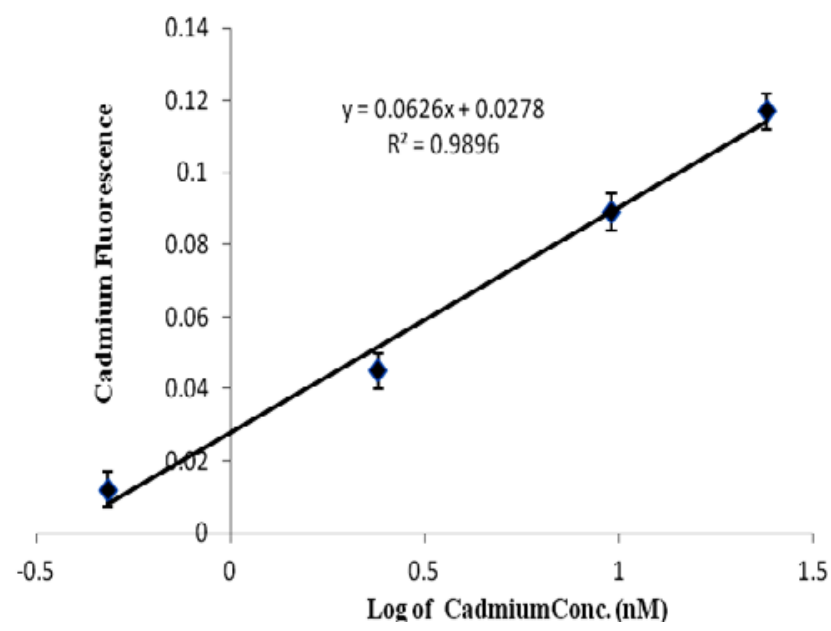

Figure 4: Logrithmic relationship of Cadmium (0.5-24 nM) with enzyme activity in spiked milk sample with acridine orange as the sensing dye (result obtained by applying standard deviation to triplicate experiments). 


\begin{tabular}{|c|c|c|c|}
\hline Sample & $\begin{array}{c}\mathbf{P b}^{2+} \text { and } \mathbf{C d}^{2+} \\
\text { Added (ng) }\end{array}$ & $\begin{array}{c}\text { Lead found } \\
\text { (ng) }\end{array}$ & $\begin{array}{c}\text { Cadmium found } \\
\text { (ng) }\end{array}$ \\
\hline Sample D4 & 5 & $4.64 \pm 0.33$ & $4.69 \pm 0.38$ \\
\hline Sample D19 & 5 & $4.88 \pm 0.26$ & $5.01 \pm 0.17$ \\
\hline Sample D20 & 5 & $5.3 \pm 0.10$ & $4.77 \pm 0.19$ \\
\hline \multicolumn{4}{|r|}{ Table 2 Reliability studies of the Optical Biosensor. }
\end{tabular}

and cadmium contamination. For this purpose three unknown samples D4, D19, D20 (which were detected negative for both $\mathrm{Pb}$ (II) and Cd (II) earlier) were spiked with $5 \mathrm{ng}$ lead and cadmium each (Table 2). It was observed that the levels of $\mathrm{Pb}$ (II) and Cd (II) added and detected by the developed method were close enough to validate the method. Applying the same method to 60 milk samples from rural, urban and industrial areas of Punjab, India, three from the industrial area were found to be contaminated. One had a lead contagion of $5.9 \mu \mathrm{M}$ and cadmium $14 \mathrm{nM}$, other was contaminated with $6 \mu \mathrm{M}$ of lead only and the last one was found to be highly contaminated with cadmium only $(87.4 \mathrm{nM})$

\section{Discussion}

The detection limit achieved in the developed biosensor (based on enzyme inhibition phenomenon) is far below the limits obtained till now and is under the permissible limit of lead in milk ( $96.6 \mathrm{nM}$ or $20 \mathrm{ng} \mathrm{ml}^{-1}$ ). No optical study based on enzyme activity has been done so far for lead contamination in milk. From the above shown data it is very evident that the developed method is suitable for lead analysis in milk samples with a very low detection limit. The obtained limit of detection in milk has not been reported by any other worker yet and the developed method surpasses the need of any pretreatment of the milk samples. It was observed that the complex matrix of milk imparts some increase in fluorescence of the dye as compared to water system. So, to detect that interference due to milk and to apply the developed method to unknown milk samples taking water as reference, the analysis of lead in water and spiked milk samples was carried out and the fluorescence read at different lead concentrations with control samples were compared. As shown in Table 1, it was observed that the difference in fluorescence of spiked milk and water samples were following a regular pattern and indicated an average fluorescence difference of 0.12 . So it could be suggested that the effect of milk on fluorescence is corresponding to 0.12 units in present study, and should be considered at the time of lead determination in unknown milk samples.

As per the earlier reports, Lee and Lee [23] developed a conductometric biosensor based on sol-gel immobilized urease and obtained a detection limit of $0.9 \mathrm{mM}$ for lead in drinking water. Later Tsai [8] used FITC- dextran as fluorescent dye to develop urease based optical biosensor for heavy metals and achieved a detection limit of $0.1 \mathrm{mM}$. Kuswandi [7] obtained a detection limit of $1{\mathrm{X} 10^{-2} \mathrm{mM} \text { lead }}^{-1}$ in $6 \mathrm{~min}$ response time using immobilized urease on an optical fiber. Then a sol-gel immobilized urease conductometric biosensor was developed by Illangovan et al. [15] and a percentage inhibition of 35\% was observed with $1 \mathrm{mM}$ lead. A very low detection limit of $4.83 \mathrm{nM}$ was achieved using cyclotetrachronotropylene (CTCT) as an indicator by Haron and Ray [10]. None of the above reports furnished any details about interfering ions. The present work has the advantage of simplicity and multiple sampling along with lower limit of detection as compared to the existing ones. Also the distinction between lead and cadmium response through the selection of different Bacillus strains and fluorescent dyes is an extra advantage of reported method.

The present method is also first of its kind to detect $\mathrm{Pb}$ (II) and $\mathrm{Cd}$
(II) simultaneously in milk. Haron and Ray [10] reported an optical biosensor for monitoring $\mathrm{Pb}$ (II) and $\mathrm{Cd}$ (II) in water samples based on inhibition of urease and acetylcholinesterase and achieved a detection limit of $1 \mathrm{ng} \mathrm{ml}^{-1}$ whereas the present work could detect upto $0.1 \mathrm{ng}$ $\mathrm{ml}^{-1} \mathrm{~Pb}$ (II) ions in milk samples. For simultaneous detection of lead and cadmium in unknown samples, standard curves for water and spiked milk samples were utilized. According to the standard curve of cadmium effect on urease, its concentration could be deduced from the change in fluorescence pattern corresponding to $\mathrm{Cd}$ (II). Taking that concentration as reference the respective fluorescence fraction of Cd (II) was subtracted from the fluorescence read with $B$. sphaericus to get the lead contamination level. As per the standards of spiked lead samples and cadmium interference values, two formulas for quantitative analysis of lead was devised which could be directly applied on unknown samples.

$\mathrm{X}$ nanomoles of $\mathrm{Pb}(\mathrm{II})=[(\mathrm{A}-\mathrm{M} 1)-\mathrm{F} 1] \times \mathrm{B} 1$, when only Rhodamine dye used

Where, $\mathrm{A}=$ Fluorescence read for the sample (corresponding to $\mathrm{Pb} \mathrm{II}$ )

M1=Milk factor with Rhodamine dye,

F1=Fluorescence read of Rhodamine G

$\mathrm{B} 1=\mathrm{Pb}$ (II) Standard/Fluorescence of that standard sample

To detect lead in the presence of cadmium a formula was devised for cadmium detection and then the fluorescence factor (interference factor) according to that cadmium concentration was subtracted from Rhodamine 6G fluorescence to detect lead contamination.

$\mathrm{X}$ nanomoles of $\mathrm{Pb}(\mathrm{II})=[\{[\mathrm{A}-\mathrm{M} 1)-\mathrm{F} 3]-\mathrm{C}\} \times \mathrm{B} 1$

Where, $A=$ Fluorescence read for the sample (corresponding to $\mathrm{Pb}$ II ), M1=Milk factor,

F3=Florescence read of combined dyes rhodamine and acridine orange,

$\mathrm{C}=$ Cadmium conc. calculated from standard curve using dye acridin orange,

\section{$\mathrm{B} 1=\mathrm{Pb}$ (II) Standard/Fluorescence of that standard sample}

Present work has resulted in development of an enzyme inhibition based microarray optical biosensor for monitoring lead equivalents in milk simultaneously with cadmium.

\section{Conclusion}

Finally it is concluded that, a reliable and cost effective lead detecting whole cell based optical biosensor has been developed for application in milk, based on urease inhibition. Microarray approach has been used to analyse multiple samples at the same time. The detection limit achieved is $0.48 \mathrm{nM}$ of $\mathrm{Pb}$ (II) equivalents in milk which is far below the permissible level $(96.6 \mathrm{nM})$. The reliability and application of the developed biosensor for lead monitoring in milk samples is checked and found to be a competent method for analysis. Present work is also first endeavor of its kind capable of detecting cadmium and lead simultaneously through different strains of urease producing Bacillus sps. The study has resulted in a fluorescence based formula for $\mathrm{Pb}$ (II) and $\mathrm{Cd}$ (II) detection in unknown milk samples without any pretreatment requirement. Exploitation of Rhodamine $-6 \mathrm{G}$ as the fluorescent indicator and the nature of its fluorescence change in the hydrophobic environment of sol-gel matrix provided the advantage of lower limit detection. The developed biosensor could be 
Citation: Hardeep K, Verma N (2015) High Throughput Optical Biosensor for Monitoring Pb (II) lons in Milk through Fluorescence based Microarray Approach. J Biosens Bioelectron 6: 166. doi:10.4172/2155-6210.1000166

Page 5 of 5

easily converted into a simple kit based assay for commercial purpose.

Acknowledgement. The authors are thankful to ICAR (NAIP), New Delhi, India for the research grant C4/C10125/2008 supporting this work.

\section{Conflict of Interest}

Dr Hardeep Kaur and Dr Neelam Verma declare that they have no conflict of interest.

\section{References}

1. Patra RC, Swarup D, Kumar P, Nandi D, Naresh R, et al. (2008) Milk trace elements in lactating cows environmentally exposed to higher level of lead and cadmium around different industrial units. Sci Total Environ 404: 6-43.

2. Sahayaraj PA, Ayyadirai K (2009) Bioaccumulation of Lead in milk of buffaloes from Cooum river belt in Chennai. $J$ Environ Biol 5: 651-654.

3. Ogabiela EE, Udiba UU, Adesina OB, Hammuel C, Ade - Ajayi FA, et al. (2011) Assessment of metal levels in fresh milk from cows grazed around Challawa industrial estate of Kano, Nigeria. J Basic Appl Sci Res 7: 533-538.

4. www.codexalimentarius.net/input/download/.../17/CXS_193e.pdf

5. Swarup D, Patra RC, Naresh R, Kumar P, Shekhar P (2005) Blood lead levels in lactating cows reared around polluted localities; transfer of lead into milk. Sci Total Environ 349: 67-71.

6. Durrieu C,Tran-Minh C (2002) Optical Algal Biosensor using Alkaline Phosphatase for determination of Heavy metals. Ecotox \& Environ safe 51: 206-209.

7. Kuswandi B (2003) Simple optical fiber biosensor based on immobilized enzyme for monitoring of trace heavy metal ions. Anal Bioanal Chem 376: 1104-1110.

8. Tsai HC, Doong RA, Chiang MS, Chen KI (2003) Sol-gel derived urease based optical biosensor for the rapid determination of heavy metals. Laxal Acta 481: 75- 84.

9. Tsai HC, Doong R (2005) Simultaneous detection of $\mathrm{pH}$, urea, acetylcholine and heavy metals using array based enzymatic optical biosensor. Biosens Bioelectron 9: 1796-1804.
10. Haron S, Ray AK (2006) Optical Biodetection of cadmium and lead ions in water. Med Eng Phys 28: 978-981.

11. Gani AA, Ashari MR, Kuswandi B (2010) An optical fiber biosensor for heavy metal ions based on o modified single sol - gel film of urease and chlorophenol red in flow system. Sensor Letters 2: 320-327.

12. Hu QZ, Jang CH (2011) Liquid crystal based sensors for the detection of heavy metals using surface immobilized urease. Colloid Surface B 2: 622-626.

13. http://www.patentstorm.us/patents/5958786.html

14. Verma N, Kaur H, Kumar S (2011) Whole cell based electrochemical biosensor for monitoring lead ions in milk. Biotechnology 3: 259-266.

15. Ilangovan R, Daniel D, Krastanov,A, Zachariah C, Elizabeth R (2006) Enzyme based biosensor for heavy metal ions determination. Biotechnol Biotech Eq 20: $184-189$

16. Ataro A, Mc Crindle RI, Botha BM, Mc Crindle CME, Ndibewu PP (2008) Quantification of trace elements in raw cow's milk by inductively coupled plasma mass spectrometry (ICP-MS). Food Chem 111: 243-248.

17. Jigam AA, Dauda BEN, Jimoh T, Yusuf HN, Umar ZT (2011) Determination of copper, zinc, lead and some biochemical parameters in fresh cow milk from different locations in Niger state, Nigeria. African J Food Sci 3:156-160.

18. Verma N, Kumar S, Kaur H (2010) Fiber Optic Biosensor for the Detection of Cd in Milk.

19. Verma N, Singh M (2006) A Bacillus sphaericus based biosensor for monitoring nickel ions in industrial effluents and foods. J Aut Meth Mgt Chem 427: 1-4.

20. Verma N, Singh M (2006b) A novel Bacillus sphaericus strain, a device comprising the said strain and a method for detecting copper in industria effluents using said device.

21. Tuzen M, Uluozlu OD, Usta C, Soylak M (2007) Biosorption of copper(II) lead(II), iron(III) and cobalt(II) on Bacillus sphaericus-loaded Diaion SP-850 resin. Anal Chim Acta 2: 241-246.

22. Shin M, Shim J, You Y, Myung H, Bang K, et al. (2012) Characterization of lead resistant endophytic Bacillus sp. MN3-4 and its potential for promoting lead accumulation in metal hyperaccumulator Alnus firma. J Hazard Material 200: 314-320.

23. Lee S, Lee W (2002) Determination of heavy metal ions using conductometric biosensor based on sol-gel immobilized urease. Bull Korean Chem Soc 23 1169- 1172. 